\title{
RETROSPECTIVE ANALYSIS OF INTERVENTIONS PERFORMED BY EMERGENCY MEDICAL TEAMS IN POLAND BEFORE AND DURING THE SARS COV-2 PANDEMIC
}

DOI: 10.36740/WLek202008113

\author{
Michał Kucap ${ }^{1,2}$, Klaudiusz Nadolny ${ }^{1,2}$, Jerzy R Ładny ${ }^{3}$, Dorota Zyśk0 ${ }^{4}$, Robert Gałązkowski ${ }^{5}$, Mariusz Gąsior ${ }^{6}$, \\ Waldemar Kraska ${ }^{7}$ \\ 'DEPARTMENT OF EMERGENCY MEDICAL SERVICE, STRATEGIC PLANNING UNIVERSITY OF DABROWA GORNICZA, DABROWA GORNICZA, POLAND \\ 2FACULTY OF MEDICINE, KATOWICE SCHOOL OF TECHNOLOGY, KATOWICE, POLAND \\ 3DEPARTMENT OF EMERGENCY MEDICINE, MEDICAL UNIVERSITY OF BIALYSTOK, BIALYSTOK, POLAND \\ ${ }^{4}$ DEPARTMENT OF EMERGENCY MEDICINE, WROCLAW MEDICAL UNIVERSITY, WROCLAW, POLAND \\ ${ }^{5}$ DEPARTMENT OF EMERGENCY MEDICAL SERVICE, MEDICAL UNIVERSITY OF WARSAW, WARSAW, POLAND \\ ${ }_{63}^{6 R D}$ DEPARTMENT OF CARDIOLOGY, SILESIAN CENTER FOR HEART DISEASES, FACULTY OF MEDICAL SCIENCES IN ZABRZE, MEDICAL UNIVERSITY OF SILESIA, \\ KATOWICE, POLAND \\ ${ }^{7}$ MINISTRY OF HEALTH, WARSAW, POLAND
}

\begin{abstract}
Introduction: The SARS-CoV-2 virus was recognized in December 2019 in China. From that moment it has quickly spread around the whole world. It causes COVID-19 disease manifested by breathlessness, coughing and high temperature. The COVID-19 pandemic has become a great challenge for humanity.

The aim: To analyze interventions of emergency medical teams during the SAR-CoV-2 pandemic, and to compare obtained data with the same periods in 2018-2019.

Material and methods: The study retrospectively analyzed interventions of emergency medical teams in the period from 15.03 to 15.05 in 2018-2020. 1,479,530 interventions of emergency medical teams were included in the study. The number of interventions, reasons for calls, and diagnoses made by heads of the emergency medical teams during the SARS-CoV-2 pandemic were compared to the same period in 2018-2019.

Results: Authors observed the decline in the number of interventions performed by emergency medical teams during the pandemic in relation to earlier years by approximately 25\%. The big decline concerned interventions that were the reason for calls to public places, such as "traffic accident" and "collapse". In the case of diagnoses made by the head of the emergency medical team, the diagnoses regarding stroke or sudden cardiac arrest remained at the similar level. Others showed a marked decline.

Conclusions: Reduced social activity contributed to a reduced number of interventions by emergency medical teams in public places. The societal fear of the unknown also contributed to the decrease in the number of interventions performed by emergency medical teams. People began to avoid contact with other people.
\end{abstract}

KEY WORDS: emergency medical teams, the SARS CoV-2 pandemic, retrospective analysis

Wiad Lek. 2020;73(8):1659-1662

\section{INTRODUCTION}

In December 2019, the information went around the world about a new virus that began to spread throughout the city of Wuhan, China. The virus was classified as a coronavirus and was named SARS-CoV-2 [1]. It turned out that the virus was rapidly spreading to other cities around the world. In Poland, the first case of SARS$\mathrm{CoV}-2$ virus transmission was registered on March 4, 2020. Accordingly, the World Health Organization (WHO), observing the current situation in the world with the spreading virus, declared the pandemic on March 20,2020. The SARS-CoV-2 virus is classified as an infectious disease. It is transferred by the droplet route. Infection with SARS-CoV-2 virus can cause a disease called COVID-19, which manifests with a high temperature above $38^{\circ} \mathrm{C}$, dry cough, and shortness of breath $[2,3]$. The SARS-CoV-2 virus outbreak in the world caused that in many countries local announcements were introduced that changed the way of everyday functioning. For example, in Poland restrictions on contacts in public places were introduced, procedures for admitting patients to hospitals were changed, and Primary Health Care (GP) switched its operation to teleconsultations [4]. This caused the emergency medical service system plays a very important role in the fight against coronavirus.

\section{THE AIM}

The aim of the study was to assess the number of interventions of emergency medical teams, the main reasons for calls, and final diagnoses made by heads of emergency medical teams based on the ICD10 code during the SAR-CoV-2 pandemic period in comparison with the same periods in 2018-2019.

\section{MATERIAL AND METHODS}

The study was carried out throughout the country, making a retrospective analysis of dispatch order cards (DOC) and med- 


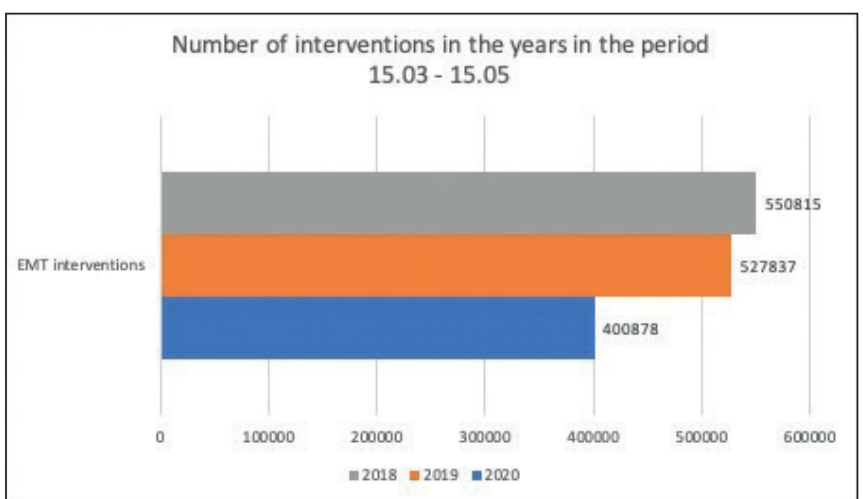

Fig. 1. The number of interventions of emergency medical teams in the period from 15.03 to 15.05 in 2018 - 2020.

Legend: EMT - emergency medical team

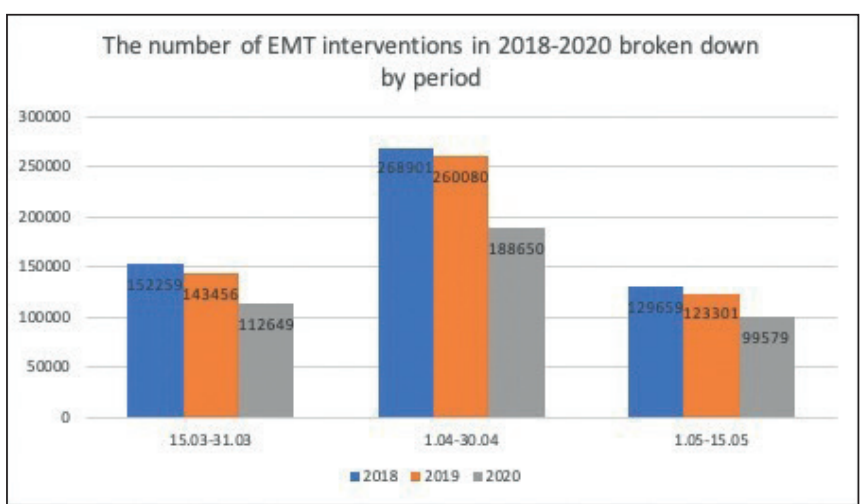

Fig. 2. The number of interventions of emergency medical teams in the period from 15.03 to 15.05 in 2018 - 2020, according to the given month. Legend: EMT - emergency medical team

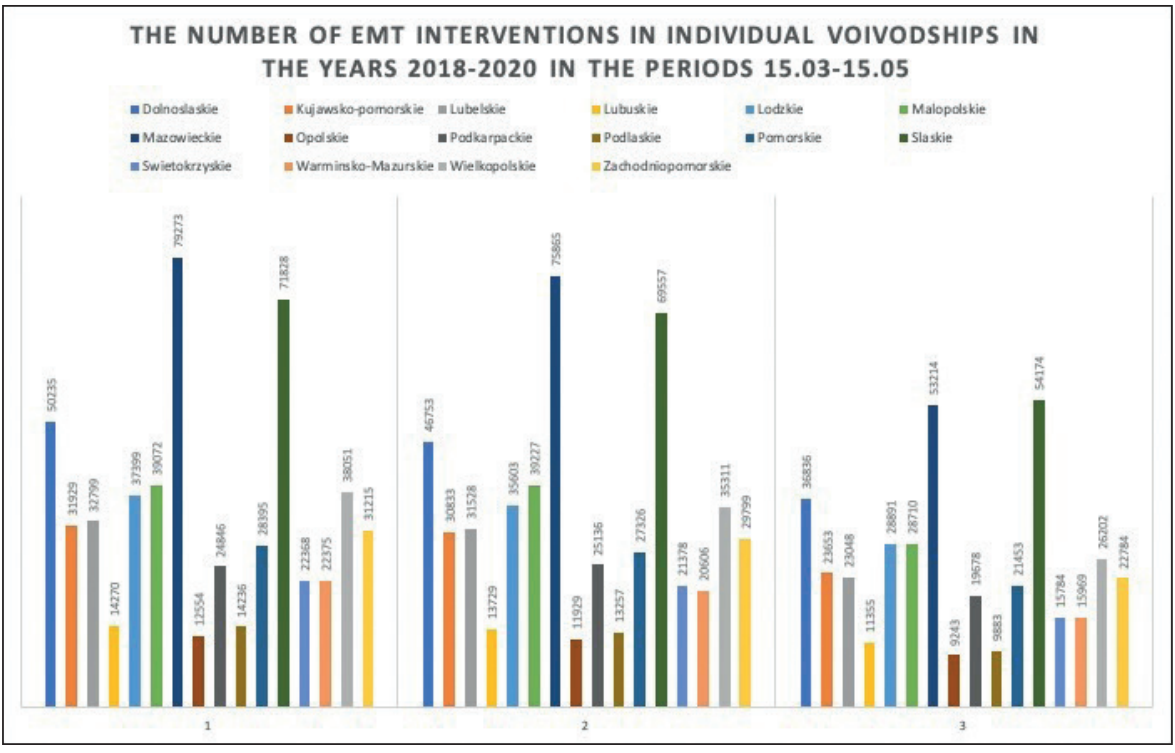

Fig. 3. The number of interventions of emergency medical teams in the period from 15.03 to 15.05 in 2018 - 2020, according to the given month.

$1-2018$

$2-2019$

$3-2020$

Legend: EMT - Emergency medical team

ical emergency services cards (MESC) in the period from 15.03 to 15.05 in 2018-2020. DOC is a card filled out by the medical dispatcher, which contains information on, among others, a categorized reason for the call. Whereas MESC is a card filled in by the head of the emergency medical team, which includes, among others, the diagnosis based on the ICD-10 code.

The acquired data covered the years 2018-2020 in the periods 15.03 - 15.05. 1,479,530 emergency medical team interventions were included in the study. The number of emergency medical team interventions divided into voivodships, categorized reasons for calls filled out by medical dispatchers, and selected final diagnoses made by the head of the emergency medical team according to the ICD-10 codes were analyzed.

The data used in the study comes from approximately 1580 emergency medical teams securing approximately 38.5 million Polish residents. The pandemic period of 15.03-15.05.2020 was compared to the same period in 2018 and 2019.

Data was obtained from the State Emergency Medical Commanding Support System with the consent of the Ministry of Health at the request of the National Consul- tant in the field of Emergency Medicine. The study did not require the consent of the bioethics committee and the patient's consent.

\section{STATISTICAL ANALYSIS}

The analysis was performed using the MICROSOFT OFFICE software. The data was entered in the EXCEL program, in which figures were created.

\section{RESULTS}

$1,479,530$ emergency medical team interventions in Poland were included in the study. There was a decrease in the number of emergency medical team interventions during the pandemic by approximately $25 \%$ in relation to the previously studied period (Fig. 1). By spreading the number of emergency medical team dispatches over individual periods, a similar decline was noted during the pandemic (Fig. 2). Analyzes in individual voivodships showed a decrease in interventions from $22 \%$ to almost 33\% (Fig. 3). Then the focus was on the role of the medi- 

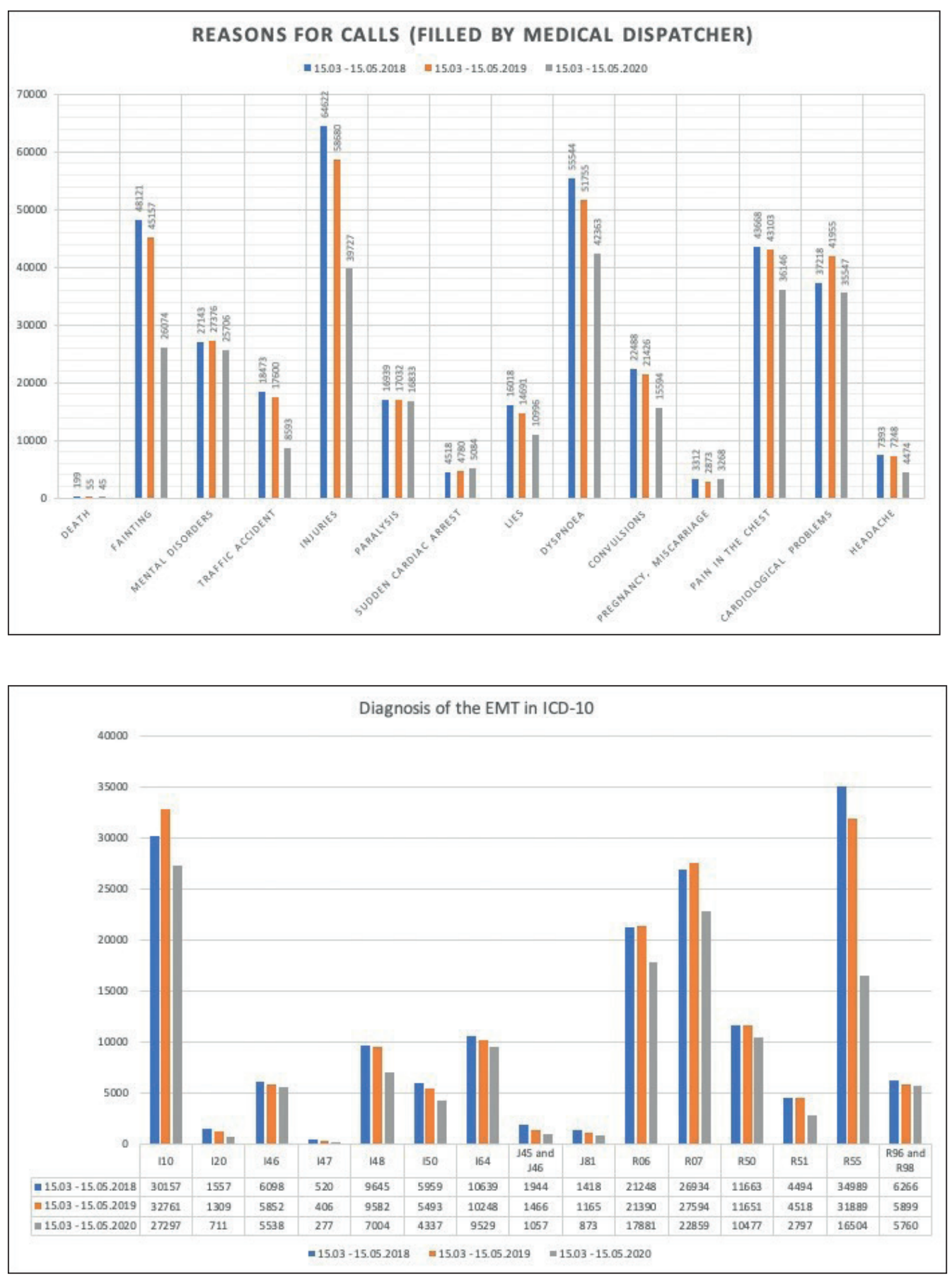

Fig. 4. Reasons for calling emergency medical teams in the period from 15.03 to 15.05 in 2018-2020.

Legend: SCA - sudden cardiac arrest

Fig.5. The final diagnosis made by emergency medical teams based on ICD-10 in the period from 15.03 to 15.05 in 2018 - 2020.

Legend: ICD-10 - International Statistical Classification of Diseases and Related Health Problems. I10 - hypertension; 120 - Coronary heart disease; 121 and 122 - acute myocardial infarction;146-sudden cardiac arrest; 147 - paroxysmal tachycardia; 148 - atrial fibrillation; 150 - heart failure; 164 - stroke; $\mathrm{J} 45$, J46 - bronchial asthma, J81 pulmonary edema, R06-shortness of breath, R07 - chest pain; R50 - fever; R51- headache; R55 fainting; R96, R98 - death. cal dispatcher. The medical dispatcher takes medical history and makes decisions on disposing the emergency medical team or refusal along with providing information on further steps. The decision is made on the basis of categorizing the reason for the calls. Figure 4 provides an overview of the reasons for calling. Another aspect taken into account was the final diagnosis of the emergency medical team head at the incident site based on ICD10. The selected diagnoses are presented in detail in Figure 5.

\section{DISCUSSION}

At the end of the last year, the information went around the world about a new, unknown virus spreading in China. From the beginning, WHO reported that it belonged to the group of coronaviruses and was transmitted by the droplet route. The virus quickly spread through the whole world [5]. At the end of May 2020, the virus has been located in 201 countries around the world and has been confirmed in almost 6 million people [6]. Many countries haveintroduced restrictions on people-to-people contacts [7]. In Poland, all mass events were canceled first. Border controls were reintroduced, and 14-day quarantine obligations for persons returning from abroad were introduced. Then, schools and colleges were closed as well as all public facilities were shuttered, including parks, playgrounds and forests [8]. These actions slowed down the spread of SARS-CoV-2 virus in Poland. Most of the population has adapted to the current regulations 
and remained at home. There was definitely reduced traffic on the streets, and thus a reduced number of traffic accidents. In addition, the decrease in social activity has contributed to the reduced number of emergency medical team interventions in the event of collapse [9]. Fainting is most common in public places, in clusters of people, where access to "fresh" oxygen is limited. Social isolation in many people caused anxiety and fear of the new virus. This could be observed after the introduction of the special Act on restrictions and isolation in Poland [10]. The part of the population increased their home supplies and isolated themselves from society by staying at home. There have been many comments on the internet about the health workers exposure to the spread of coronavirus. Some supported this fight, but unfortunately there was sometimes a wave of hatred, which contributed to avoiding contact with the healthcare facilities [11]. The concerns were related to the risk of infection or possible hospitalization in hospitals among people with symptoms of COVID-19 disease. This had a significant impact on reducing the number of emergency medical team interventions during the pandemic. In the work of Chourasia et al. we read that during the pandemic the number of patients in the Hospital Emergency Department (SOR) decreased by about 23\% [12]. The question should be asked whether the above-mentioned fears have not really contributed to the fact that often people with disturbing symptoms concerning their state of health waited with a call for help hoping that the symptoms would subside [13].

\section{CONCLUSIONS}

1. The number of categorized reasons for calls related to the intervention of emergency medical teams in public places decreased significantly during the pandemic.

2. The decrease in the number of emergency medical team interventions during the pandemic in some voivodships reached over $30 \%$ compared to previous years.

3. Despite the reduced number of emergency medical team interventions associated with the spreading virus, the number of calls for sudden cardiac arrest was similar.

\section{LIMITATIONS}

The authors do not have data on the further outcomes of patients.

\section{REFERENCES}

1. Xiaoyi H, Fengxiang WLH, Lijuan W, et al. Epidemiology and Clinical Characteristics of COVID-19. Arch Iran Med. 2020; 1; 23: 268-271

2. Sasmita P. A, Sha M, Yu-Ju W, et al. Epidemiology, Causes, Clinical Manifestation and Diagnosis, Prevention and Control of Coronavirus Disease (COVID-19) During the Early Outbreak Period: A Scoping Review Infect Dis Poverty, 2020; 9:29.

3. Nowak B, Szymański P, Pańkowski I, et al. Clinical characteristics and short-term outcomes of patients with coronavirus disease 2019: a retrospective single-center experience of a designated hospital in Poland. Pol Arch Intern Med. 2020 may 29 (ahead of print)

4. Świerad M, Dyrbuś K, Szkodziński J, et al. Telehealth visits in a tertiary cardiovascular centre as a response of the healthcare system to the pandemic of SARS-CoV-2 in Poland. Pol Arch Intern Med. 2020 may 19 (ahead of print).
5. Tanu S. A Review of Coronavirus Disease-2019 (COVID-19). Indian J Pediatr., 2020; 87: 281-286.

6. https://www.worldometers.info/coronavirus (Accessed: 02.06.2020).

7. Google S. California Coronavirus (COVID-19) Response Stay home except for essential needs. Available at: [https://covid19.ca.gov/stay-homeexcept-for-essential-needs (accessed 7.06.2020)].

8. Ustawa z dnia 2 marca 2020 r. o szczególnych rozwiązaniach związanych z zapobieganiem, przeciwdziałaniem i zwalczaniem COVID-19, innych chorób zakaźnych oraz wywołanych nimi sytuacji kryzysowych. Dz.U. 2020; poz. 374.

9. Maudet L, Sarasin F, Dami F, etal. Emergency Medical Services: COVID-19. Crisis Rev Med Suisse. 2020; 16: 810-814.

10. Rozporządzenie Ministra Zdrowia z 20.03.2020 w sprawie ogłoszenia na obszarze Rzeczypospolitej Polskiej stanu epidemii. Dz.U. 2020; poz. 491

11. Legutko J, Niewiara $t$, Bartuś $S$, et al. The decline of coronary angiography and percutaneous coronary intervention procedures in patients with acute myocardial infarction in Poland during the COVID-19 pandemic. Kardiol Pol. 2020 may 27 (ahead of print).

12. Chourasia G, Sycz W, Wolniakowski I, et al. Changes in the visits to emergency department of non-infectious hospital during the early Covid-19 state of epidemic. Emerg Med Serv, 2020;7(2):99-102.

13. https://www.escardio.org/Education/COVID-19-and-Cardiology/ patients-scared-and-alone-pavia-italy. (accessed: 03.06.2020)

\section{Acknowledgment}

Authors would like to thank the Ministry of Health for providing data from the State Emergency Medical Commanding Support System, what made possible to conduct the study.

\section{Conflict of interest}

Authors declare no conflict of interest.

\section{Authors ORCID and contributionship}

Michat Kucap - 0000-0003-1150-8304 ${ }^{A, D}$

Klaudiusz Nadolny - 0000-0003-0355-241X B,E,F

Jerzy Robert Ładny - 0000-0003-4167-1962 ${ }^{B}$

Dorota Zyśko - 0000-0001-9190-0052 ${ }^{C}$

Robert Gałazkowski - 0000-0002-7205-2219 E, F

Mariusz Gasior - 0000-0001-6775-1392 A, F

Waldemar Kraska ${ }^{B}$

\section{CORRESPONDING AUTHOR}

\section{Michał Kucap}

Department of Emergency Medical Service, Strategic Planning University of Dabrowa Gornicza, Kościelna Street 8, 41-303 Dąbrowa Górnicza

tel: +48513189190

e-mail:mkucap@wpr.pl

Received: 22.06 .2020

Accepted: 13.08 .2020

A - Work concept and design, B - Data collection and analysis, C - Responsibility for statistical analysis,

D-Writing the article, $\mathbf{E}$-Critical review, $\mathbf{F}-$ Final approval of the article 